\title{
Flavonoids and phenolic acids from pearl millet (Pennisetum glaucum) based foods and their functional implications
}

\author{
Vanisha S Nambiar', Neha Sareen ${ }^{1}$, Mammen Daniel ${ }^{2}$, and Erick B Gallego ${ }^{3}$
}

${ }^{1}$ Department of Foods and Nutrition, A WHO Collaborating Center for Promoting Health and Nutrition, Faculty of Family and Community Sciences, The M S University of Baroda, Vadodara, Gujarat, 390002, India; ${ }^{2}$ Division of Phytochemistry, Department of Botany, Faculty of Science, The MS University of Baroda, Vadodara, Gujarat, 390002, India; ${ }^{3}$ Harvest Plus, c/o IFPRI/CIAT, 2033 K Street, NW, Washington, DC 20006, USA

Corresponding author: Vanisha S. Nambiar, PhD; Department of Foods and Nutrition, A WHO Collaborating Center for Promoting Health and Nutrition, Faculty of Family and Community Sciences, The MS University of Baroda, Vadodara, Gujarat, 390002, India

Submission date: May 08, 2012, Acceptance date: June 29, 2012; Publication date: July 5, 2012

\section{ABSTRACT}

Background: Pearl millet (Pennisetum glaucum), considered a poor man's cereal, may be a repository of dietary antioxidants, especially flavonoids and phenolic acids, which provide bioactive mechanisms to reduce free radical induced oxidative stress and probably play a role in the prevention of ageing and various diseases associated with oxidative stress, such as cancer, cardiovascular, and neurodegenerative diseases.

Objective: The present study focused on the identification of individual flavonoids and phenolic acids from seven commercial varieties of pearl millet and five samples of pearl millet-based traditional recipes of Banaskantha, Gujarat, India.

Methods: Total phenols were determined by the Folin-Ciocalteu method, and individual polyphenol separation included the isolation and identification of (a) flavonoids, (b) phenolic acids, and (c) glycoflavones involving interaction with diagnostic reagents and paper chromatographic separation of compounds and their UV-visible spectroscopic studies including hypsochromic and bathchromic shifts with reagents such as $\mathrm{AlCl} 3, \mathrm{AlCl} 3 / \mathrm{HCl}, \mathrm{NaOMe}, \mathrm{NaOAc}$, and $\mathrm{NaOAc} / \mathrm{H} 3 \mathrm{PO}$. Five traditional recipes consumed in the pearl millet producing belt of Banaskantha, Gujarat, India, were standardized in the laboratory and analyzed for phenol and individual flavonoids.

Results: Total phenols in raw samples ranged from 268.5 - 420mg/100g of DW and 247.5 $335 \mathrm{mg} / 100 \mathrm{~g}$ of $\mathrm{DW}$ in cooked recipes. The commonly identified flavonoids were tricin, 
acacetin, 3, 4 Di-OMe luteolin, and 4-OMe tricin. Five phenolic acids were identified: namely vanilic acid, syringic acid, melilotic acid, para-hydroxyl benzoic acid, and salicylic acid.

Conclusion: The presence of flavonoids, such as tricin, acacetin, 3, 4 Di-OMe luteolin, and 4OMe tricin, indicate the chemopreventive efficacy of pearl millet. They may be inversely related to mortality from coronary heart disease and to the incidence of heart attacks in the pearl millet consuming belts of the world.

Keywords: Polyphenols, Antioxidant, Flavonoids, Total Phenols, Pearl Millet (raw and cooked) (Pennisetum glaucum), Banaskantha, Gujarat.

\section{INTRODUCTION:}

Pearl millet (Pennisetum glaucum (L.) R. Br.), is the most popular cereal crop grown in tropical semi-arid regions of the world. Locally known as Bajra in Gujarat, a western state of India, the total area in which pearl millet is produced in Gujarat is 7033 ha [2008-2009] [1]. Gujarat ranks third in pearl millet yield compared to all other states in India [2]. In Gujarat, the highest production is found in the northern plains of Banaskantha $(2558 \mathrm{mt})$. Banaskantha is one of the 25 administrative districts, located in the northeast part of Gujarat. It produces $26.61 \%$ of pearl millet, followed by wheat $(11.7 \%)$, as per the season crop report of 2007-2008 of Gujarat Government.

The commonly consumed recipes in Banaskantha are pearl millet based, namely; rotla, khichadi, kuler, ghes, and matar, since this cereal occupies major area and yield among different Kharif crops (planted for autumn harvest, may also be called the summer or monsoon crop in India, sown with the beginning of the first rains in July, during the south-west monsoon season) followed up by pulses such as Cicer arietinum L. (chickpea), Vigna radiata (L). Wilczek (green gram), Vigna mungo (L.) Hepper (black gram), Pisum sativum L. (field pea) and Cajanus cajan (L.) Millsp. (red gram or pegion pea) and Sorghum bicolor (sorghum, jowar). Among the 31 varieties of pearl millet recorded from this district, Dhanya 7882, Pioneer 86M52, Daha Grade seeds 555, Pioneer 86M64 (summer and Monsoon), and Pioneer 9444 are popularly consumed by the majority of people of Banaskantha district of Gujarat [3].

Though this cereal is rich in energy, protein, fat, and iron (NIN 2003) [4], no studies are available on the values of the total and individual polyphenol content of raw and cooked Indian pearl millet (commonly known as bajra) based recipes of Banaskantha, Gujarat.

Dietary antioxidants present in commonly consumed foods, especially the flavonoids and phenolic acids such as quercetin, kaempferol, and acacetin, and phenolic acids: vanillic acid, ferulic acid (cis and trans form), and p-coumaric acid, melilotic, and provide bioactive mechanisms to reduce free radical induced oxidative stress and their probable role in the prevention of ageing and various diseases associated with oxidative stress, such as cancer, cardiovascular and neurodegenerative diseases [5-9].

Pearl millet has been recommended for several therapeutic purposes, as it has been found to inhibit tumor development [10], control blood pressure and plasma low density lipo protein cholesterol levels [11], and possesses anti-allergenic characteristics. Due to its high fiber content, 
pearl millet is also recommended for the treatment of severe constipation, stomach ulcers, and weight loss Its nutrient and non-nutrient (especially the phytochemicals) database, which may represent the underlying mechanism of these nutraceutical effects, needs to be established. The present study assessed the total phenol contend and identified individual polyphenols of raw and cooked pearl millet based recipes consumed in Banaskantha district of Gujarat, a western Indian state.

\section{METHODS AND MATERIALS:}

Sampling of raw pearl millet seeds. Based on the desk review and personal interviews with key informants and focus group discussions described in our earlier report [12], a total of 31 varieties of pearl millet were identified in Gujarat. Of these six popular varieties of pearl millet from private firms in Banaskantha were selected for the present study. These were Dhanya 7882, Pioneer 86M52, Daha grade seeds 555, Pioneer 86M64 summer, Pioneer 86M64 monsoon, and Pioneer 9444 (Table 1). Another sample of mixed variety and a commercially milled flour of mixed variety were also selected.

One $\mathrm{kg}$ of seeds for each variety and commercially milled flour were collected from the 30 villages of three blocks of Banaskantha district in Gujarat, packed in clean new polyethylene plastic bags, labeled, and brought to the laboratory. Same varieties were mixed and analyzed in the laboratory for total and individual phenols.

Table 1: Characteristics and Origin of the 13 Samples of Pearl Millet Selected for the Present Study

\begin{tabular}{|c|c|c|c|c|}
\hline S. No. & Name of the variety & Type & Colour & Origin \\
\hline 1. & Dhanya, 7882 & $\begin{array}{l}\text { Raw, local } \\
\text { variety }\end{array}$ & $\begin{array}{l}\text { Irregular greyish } \\
\text { seeds }\end{array}$ & Gujarat \\
\hline 2. & Pioneer, 86M52 & $\begin{array}{l}\text { Raw, local } \\
\text { variety }\end{array}$ & $\begin{array}{l}\text { Irregular shaped } \\
\text { greyish seeds }\end{array}$ & Gujarat \\
\hline 3. & (DAHA) Grade Seeds 555 & $\begin{array}{l}\text { Raw, local } \\
\text { variety }\end{array}$ & $\begin{array}{l}\text { Light and dark green } \\
\text { round granules }\end{array}$ & Gujarat \\
\hline 4. & Pioneer 86M64, Summer & $\begin{array}{l}\text { Raw, local } \\
\text { variety }\end{array}$ & $\begin{array}{l}\text { Light green round } \\
\text { pellets }\end{array}$ & Gujarat \\
\hline 5. & Pioneer 86M64, Monsoon & $\begin{array}{l}\text { Raw, local } \\
\text { variety }\end{array}$ & $\begin{array}{l}\text { Irregular shaped } \\
\text { greyish seeds }\end{array}$ & Gujarat \\
\hline 6. & Pioneer 9444, Summer & $\begin{array}{l}\text { Raw, local } \\
\text { variety }\end{array}$ & $\begin{array}{l}\text { Light green and grey } \\
\text { granules }\end{array}$ & Gujarat \\
\hline 7. & $\begin{array}{l}\text { Mixed Variety (Dhanya 7882, Pioneer } \\
\text { 86M52, (DAHA) Grade Seeds 555, } \\
\text { Pioneer 86M64 (Summer), Pioneer } \\
\text { 86M64 Monsoon, Pioneer 9444, } \\
\text { Summer + LST GHB558, LST GHB } \\
\text { 719, LST GHB 732, LST GHB 538, } \\
\text { LST GHB 915, LST GHB 744) }\end{array}$ & $\begin{array}{l}\text { Local and } \\
\text { varieties } \\
\text { developed by } \\
\text { SDAU }\end{array}$ & $\begin{array}{l}\text { Irregular green and } \\
\text { grey granules }\end{array}$ & Gujarat \\
\hline
\end{tabular}


Sampling for cooked recipes. Based on the data collected from the ongoing project on the consumption patterns of pearl millet (Pennisetum glaucum) from 1077 women residing in 30 clusters of pearl millet belt of Banaskantha, Gujarat, India (using a qualitative research methodology-focus group discussion), the five most popularly consumed pearl millet based foods - rotla, khichadi, kuler, ghes, and sukhadi (matar) were selected for the estimation of total phenols and individual polyphenol identification (Table 2).

Five records for each recipe were noted from 6 villages selected on the basis of random sampling wherein the local women prepared the pearl millet based recipes in their traditional manner. These were standardized in the field by our field investigators with the help of standard cups (size C1 (200ml), C2 (100ml), C3 (80ml) and C4 $(50 \mathrm{ml})$ and spoons (size 1Tbsp, 1Tsp, $1 / 2 \mathrm{Tsp}$ and $1 / 4 \mathrm{Tsp}$ ) along with video recordings. These recipes were brought to the laboratory, dried in a hot air oven, and stored in autoseal polythene plastic pouches kept in airtight containers until further analysis was completed at room temperature.

Table 2: Characteristics and Origin of the Cooked and Processed Samples of Pearl Millet Selected for the Present Study

\begin{tabular}{|c|c|c|c|}
\hline S.no & $\begin{array}{l}\text { Name of the } \\
\text { Sample }\end{array}$ & Sample preparation & Origin \\
\hline 1. & Rotla & $\begin{array}{l}\text { Milled pearl millet with added salt, prepared as } \\
\text { a dough, rolled, and roasted on dry heat; eaten } \\
\text { regularly as a bread substitute }\end{array}$ & $\begin{array}{l}\text { Collected from the } \\
\text { field households }\end{array}$ \\
\hline 2. & Matar & $\begin{array}{l}\text { Milled pearl millet, roasted with ghee and } \\
\text { jiggery; a sweet dish prepared occasionally }\end{array}$ & $\begin{array}{l}\text { Collected from the } \\
\text { field households }\end{array}$ \\
\hline 3. & Khichadi & $\begin{array}{l}\text { Soaked and cooked pearl millet in open/closed } \\
\text { pan with addition of salt and spices; a regular } \\
\text { meal }\end{array}$ & $\begin{array}{l}\text { Collected from the } \\
\text { field households }\end{array}$ \\
\hline 4. & Kuler & $\begin{array}{l}\text { Milled pearl millet, mixed raw with ghee and } \\
\text { jiggery; a sweet dish prepared occasionally }\end{array}$ & $\begin{array}{l}\text { Collected from the } \\
\text { field households }\end{array}$ \\
\hline 5. & Ghes & $\begin{array}{l}\text { Hand pounded, cooked with water and } \\
\text { buttermilk; a regular meal }\end{array}$ & $\begin{array}{l}\text { Collected from the } \\
\text { field households }\end{array}$ \\
\hline 6. & Flour & Commercially machine milled pearl millet & $\begin{array}{l}\text { Collected from the } \\
\text { field households }\end{array}$ \\
\hline
\end{tabular}

Chemicals. Sodium carbonate, copper sulphate - sodium potassium tartarate solution $\left(\mathrm{CuSO}_{4} .5 \mathrm{H}_{2} \mathrm{O}\right)$, Folin-Ciocalteu reagent, dilute methanolic extract $\left(0.5 \mathrm{ml}\right.$ of $\left.1: 10 \mathrm{~g} \mathrm{ml}^{-1}\right)$, gallic acid (standard phenolic compound), (conc. HCL:acetic acid:water; 30:30:10) or glacial acetic acid, $\mathrm{Na}_{2} \mathrm{CO}_{3}, \mathrm{FeCl}_{3}$, benzene, acetic acid, sodium formate, formic acid, para nitra aniline, and sulphanic acid were purchased from Durga Scientific Pvt. Ltd, Vadodara, Gujarat, India.

Solutions. Benzene:acetic acid:water (6:7:3, upper organic layer) in the first direction and sodium formate:formic acid:water (10:1:200) in the second direction were used as irrigating 
solvent in phenolic acid estimation using paper chromatography. For diazotization in phenolic acid, $0.7 \mathrm{~g}$ of $\mathrm{p}$-nitraniline/sulphanilic acid were used.

Identification and quantification of individual phenols and total phenols. Identification of individual polyphenols was carried out as per Mabry et al, 1970 [13] using paper chromatography. The standard analytical procedures involving interaction with diagnostic reagents, i.e. spectroscopic grade methanol and paper chromatographic separation of compounds and their UV-visible spectroscopic studies including hypsochromic and bathochromic shifts with reagents such as $\mathrm{AlCl}_{3}, \mathrm{AlCl}_{3} / \mathrm{HCl}, \mathrm{NaOMe}, \mathrm{NaOAc}$, and $\mathrm{NaOAc} / \mathrm{H}_{3} \mathrm{PO}_{3}$, were followed for the identification of flavonoids and other phenolics. The UV absorption spectra of these compounds were recorded in methanol using 'Perkin - Eluer Lambda $25 \mathrm{UV} / \mathrm{V}_{\mathrm{B}}$ spectrophotometer. The identities of all the compounds (flavonoids and phenolic acids) were confirmed by paper chromatography with authentic samples $[13,14,15]$.

Determination of the total phenol content. Total phenols were determined by Folin-Ciocalteu method Lowry et al, 1951 [16] and measured at $765 \mathrm{~nm}$. The results are given in $1 \mathrm{~g}$ of Gallic acid equivalents (GAE) per g dry weight (DW) [17]. The Folin-Ciocalteu method for determination of phenolic compounds is similar to antioxidant activity determination; therefore, the values should at least partially express antioxidant activity [18].

\section{RESULTS AND DISCUSSION:}

Total phenol content in raw and cooked pearl millet. The total phenol content of raw varieties ranged from 268.5 to $420 \mathrm{mg} / 100 \mathrm{~g}$, the highest in Pioneer 9444 and lowest in Dhanya 7882 . Total phenols in cooked pearl millet based recipes ranged from $247.5-335 \mathrm{mg} / 100 \mathrm{~g}$, the highest levels in khichadi and lowest in matar. A $9.33 \%$ difference was recorded indicating a reduction in total phenol in all cooked samples as compared to the raw varieties (Table 3 and 4).

Table 3: Results of Total Phenol from Raw Pearl Millet Samples

\begin{tabular}{|c|c|c|}
\hline S. No. & Varieties of pearl millet & $\begin{array}{l}\text { Total phenols } \\
(\mathrm{mg} / 100 \mathrm{~g} \text { DW) }\end{array}$ \\
\hline 1. & Dhanya, 7882 & 268.5 \\
\hline 2. & Pioneer, 86M52 & 330 \\
\hline 3. & (DAHA) Grade Seeds 555 & 332.5 \\
\hline 4. & Pioneer 86M64, Summer & 270 \\
\hline 5. & Pioneer 86M64, Monsoon & 315 \\
\hline 6. & Pioneer 9444, Summer & 420 \\
\hline 7. & Mixed variety & 330 \\
\hline \multirow[t]{3}{*}{8.} & Flour (machine milled) & 315 \\
\hline & Mean \pm SD & 322.6 \\
\hline & RANGE & $268.5-420$ \\
\hline
\end{tabular}

On average, processed/cooked recipes of pearl millet in the present study had lower total phenol content then their unprocessed counterparts. Among the cooked samples, khichadi, which 
is subjected to processing methods like soaking, had higher total phenol content compared to other cooked samples, which were subjected to milling and roasting. The results of total phenols $(273 \mathrm{mg} / 100 \mathrm{~g}$ and 306.7 to $669.4 \mathrm{mg} / 100 \mathrm{~g})$ are comparable with those of different investigators including Singh et al and Samia et al [19-20]. Other investigators [21-24] have stated that the different processing method significantly reduced the polyphenol content. Reduction in polyphenol may be attributed to the removal of the outer layer of the grain, which was reported to be rich in polyphenols, possibly attributable to the presence of phenolic oxidase during germination. The decrease in polyphenols during fermentation of processed grains indicates the ability of micro flora to ferment phenolics, as reported by Bravo et al [25].

Table 4: Results of Total Phenol for Cooked Pearl Millet Based Recipes from Banaskantha

\begin{tabular}{|c|c|c|c|}
\hline S. No. & $\begin{array}{l}\text { Names of the pearl millet based cooked } \\
\text { recipes }\end{array}$ & $\begin{array}{c}\text { Dry } \\
\text { matter } \\
(\%)\end{array}$ & $\begin{array}{l}\text { Total phenol } \\
(\mathrm{mg} / \mathbf{1 0 0 g})\end{array}$ \\
\hline 1. & Rotla (milled and roasted on dry heat) & 62 & 317.5 \\
\hline 2. & Matar (milled, roasted with ghee and jaggery) & 94 & 247.5 \\
\hline 3. & $\begin{array}{l}\text { Khichadi (soaked and cooked in open/closed } \\
\text { pan) }\end{array}$ & 38 & 335 \\
\hline 4. & $\begin{array}{l}\text { Kuler (milled and mixed raw with ghee and } \\
\text { jaggery) }\end{array}$ & 94 & 297.5 \\
\hline \multirow[t]{3}{*}{5.} & $\begin{array}{l}\text { Ghes (hand pounded, cooked with water and } \\
\text { buttermilk) }\end{array}$ & 34 & 265 \\
\hline & Mean & 64.4 & 292.5 \\
\hline & Range & 38-94 & $247.5-335$ \\
\hline
\end{tabular}

The polyphenols compounds are usually present in the grains of cereals [26-27]. They affect the (28) bioavailability of the minerals [29-32], the digestibility of carbohydrates [33-35], and inhibit the activity of proteolytic and amylolytic enzymes [36-39].

The method of extracting components from plant material is an important factor in measurements of individual phenols and total phenols. Therefore, before analyzing the individual and total phenols, the plant material was extracted with methanol. Park and Chin [40] recently observed that methanol extracted garlic had a greater TPC, DPPH radical scavenging activity, and reducing power than water extracted. Strail et al [41] used an aqueous methanol (1:1, v/v) to extract polyphenols from various plants, including Allium species.

Individual flavonoids identified in raw and cooked pearl millet. The flavonoids identified in raw and cooked pearl millet based traditional recipes (namely rotla, khichadi, kuler, ghes, and matar) were tricin, acacetin, 3-OMe tricin and 3,4-di-OMe luteolin (Table 5 and 6). Among the six varieties of grains, Tricin, Acacetin, and a new compound 3,4-di-OMe luteolin were identified in Pioneer 86M64, summer variety. In all the cooked samples, Tricin was commonly reported; however, acacetin and 4-OMe Tricin were absent in kuler and rotla. Flavonoids such as kaempferol, 4- OMe Kaempferol, 7'4 -di-OMe Kaempferol, Quercitin, 3'-OMe Quercitin, 4- 
OMe Quercitin, 3,4-di-OMe Quercitin, gossypetin, quercetagetin, proanthocyanidin, anthocyanidin, and coumirins were not identified in raw or cooked pearl millet (Table 5).

Table 5: Results of Flavonoids from Raw Pearl Millet Samples

\begin{tabular}{|c|c|c|c|c|c|}
\hline \multirow{2}{*}{$\begin{array}{l}\text { S. No. } \\
\text { Privat }\end{array}$} & \multirow[t]{2}{*}{ Sample Name } & \multicolumn{2}{|c|}{ Visible UV Color } & \multirow[t]{2}{*}{$\lambda \max$} & \multirow[t]{2}{*}{ Flavanoid Present } \\
\hline & & & & & \\
\hline 1. & Dhanya, 7882 & Colourless & Brown & 347.93 & Tricin \\
\hline 2. & Pioneer, 86M52 & Colourless & Brown & $\begin{array}{l}347.93,326.96 \text {, and } \\
269.95\end{array}$ & Tricin, Acacetin \\
\hline 3. & $\begin{array}{l}\text { (DAHA) Grade } \\
\text { Seeds } 555\end{array}$ & Colourless & Brown & $341.69,268.50$ & Tricin, 4-Ome Tricin \\
\hline 4. & $\begin{array}{l}\text { Pioneer 86M64, } \\
\text { Summer }\end{array}$ & Colourless & Brown & 342.65 and 268.32 & 4-OMe Tricin \\
\hline 5. & $\begin{array}{l}\text { Pioneer 86M64, } \\
\text { Monsoon }\end{array}$ & Colourless & Brown & $\begin{array}{l}343.86 \text { and } 268.58 \\
341.06 \text { and } 269.32 \\
329.85 \text { and } 269.75\end{array}$ & $\begin{array}{l}\text { Tricin, 3, 4- Di-OMe } \\
\text { luteolin, Acacetin }\end{array}$ \\
\hline 6. & $\begin{array}{l}\text { Pioneer } 9444, \\
\text { Summer }\end{array}$ & Colourless & Brown & $\begin{array}{l}347.80 \text { and } 276.99 \\
346.48 \text { and } 270.89 \\
332.95 \text { and } 269.79\end{array}$ & $\begin{array}{l}\text { 3, 4- Di-Ome luteolin, } \\
\text { Acacetin }\end{array}$ \\
\hline 7. & Mixed Variety & Colourless & Brown & $\begin{array}{l}349.65 \text { and } 269.43 \\
343.02 \text { and } 269.88 \\
327.06 \text { and } 270.17\end{array}$ & $\begin{array}{l}\text { Tricin, Acacetin, 4-Ome } \\
\text { Tricin }\end{array}$ \\
\hline 8. & Flour & Colourless & Brown & $\begin{array}{l}346.14 \text { and } 269.17 \\
342.76 \text { and } 269.72\end{array}$ & Tricin, 4-Ome Tricin \\
\hline
\end{tabular}

Table 6: Results of Flavonoids for Cooked Pearl Millet Based Recipes from Banaskantha

\begin{tabular}{|c|c|c|c|c|c|}
\hline S. No. & Sample Name & $\begin{array}{l}\text { Visible UV } \\
\text { Color }\end{array}$ & & $\lambda \max$ & Flavanoid Present \\
\hline 1. & $\begin{array}{l}\text { Rotla (milled and roasted } \\
\text { on dry heat) }\end{array}$ & Colourless & Brown & 347.93 & Tricin \\
\hline 2. & $\begin{array}{l}\text { Matar (milled, roasted } \\
\text { with ghee and jaggery) }\end{array}$ & Colourless & Brown & $\begin{array}{l}347.93 \\
342.65 \text { and } 268.32 \\
326.96 \text { and } 269.95\end{array}$ & $\begin{array}{l}\text { Tricin, Acacetin, 4- } \\
\text { Ome Tricin }\end{array}$ \\
\hline 3. & $\begin{array}{l}\text { Khichadi (soaked and } \\
\text { cooked in open/closed } \\
\text { pan) }\end{array}$ & Colourless & Brown & $\begin{array}{l}349.65 \text { and } 269.43 \\
343.02 \text { and } 269.88 \\
332.95 \text { and } 269.79\end{array}$ & $\begin{array}{l}\text { Tricin, Acacetin, } 4- \\
\text { Ome Tricin }\end{array}$ \\
\hline 4. & $\begin{array}{l}\text { Kuler (milled and mixed } \\
\text { raw with ghee and } \\
\text { jaggery) }\end{array}$ & Colourless & Brown & $\begin{array}{l}346.14 \text { and } 269.17 \\
342.76 \text { and } 269.72\end{array}$ & Tricin, 4-Ome Tricin \\
\hline 5. & $\begin{array}{l}\text { Ghes (hand pounded, } \\
\text { cooked with water and } \\
\text { buttermilk) }\end{array}$ & Colourless & Brown & $\begin{array}{l}349.65 \text { and } 269.43 \\
342.65 \text { and } 268.32 \\
326.96 \text { and } 269.95\end{array}$ & $\begin{array}{l}\text { Tricin, Acacetin, 4- } \\
\text { Ome Tricin }\end{array}$ \\
\hline
\end{tabular}


Tricin is abundant in millet, oats, and wheat. Tricin has been shown to have anticancer effects in the lower gut [42]. Moreover, Tricin has a relaxant effect on smooth muscle of intestinal tissues, powerful antioxidant effects [43], potent antihistaminic activity [44], and growth inhibition of human malignant breast tumor cells and colon cancer cells [45-46]. In addition, Tricin was recently shown to interfere with murine gastrointestinal carcinogenesis and is considered safe for clinical development as a cancer chemopreventive agent [47]. An acylated Tricin glycoside from sugarcane (Saccharumofficinarum L., Gramineae) juice exhibits in vitro antiproliferative activity against several human cancer cell lines with a higher selectivity toward cells of breast-resistant NIC/ADR line [48]. Flavonoids have been shown to modify eicosanoid biosynthesis (antiprostanoid and anti-inflammatory responses), protect low density lipoprotein (LDL) from oxidation (prevention of atherosclerotic plaque formation), and promote relaxation of cardiovascular smooth muscle (antihypertensive, antiarrhythmic effects). In addition, flavonoids have been shown to have antiviral and anticarcinogenic properties [49].

Flavonoids as antioxidants may inhibit the oxidation of LDL cholesterol, reduce platelet aggregation, or reduce ischemic damage. Since flavonoids have good antioxidant property, they are referred to as "nature's biological response modifiers", because they modify the body's reaction to pathogens as well as compounds such as allergens and carcinogens. They are powerful antioxidants giving protection against oxidative and free radical damage. They prevent formation of oxidized cholesterol through antioxidant effects. Flavonoids exert greater antioxidant effects than vitamin $\mathrm{C}$, vitamin $\mathrm{E}$, selenium, and zinc. Epidemiological studies have shown that flavonoid intake is inversely related to mortality from coronary heart disease and to the incidence of heart attacks, and that certain flavonoids can protect LDL from being oxidized and prevent atherosclerosis. In addition, a great number of plant medicines contain flavonoids, which have been reported by many authors as having antibacterial, anti-inflammatory, antiallergic, antimutagenic, antiviral, antineoplastic, anti-thrombotic, and vasodilatory actions [50].

Table 7: Results of Phenolic Acid from Raw Pearl Millet Samples

\begin{tabular}{lll}
\hline S. No. & Sample Name & Phenolic Acid Present \\
\hline $\mathbf{1 .}$ & Dhanya, 7882 & Syringic, salicylic, p-OH benzoic acid \\
$\mathbf{2}$ & Pioneer, 86M52 & Syringic, salicylic, p-OH benzoic acid \\
$\mathbf{3}$ & (DAHA) Grade Seeds 555 & Vanillic, syringic, p-OH benzoic acid \\
4. & Pioneer 86M64, Summer & Vanillic, p-OH benzoic acid \\
5. & Pioneer 86M64, Monsoon & Vanillic, syringic, melilotic acid \\
6. & Pioneer 9444, Summer & Vanillic, syringic, melilotic acid \\
7. & Mixed variety & Vanillic, syringic, salicylic, melilotic acid \\
8. & Flour & Vanillic acid, syringic acid, p-OH benzoic acid, \\
& & o-coumaric acid, p-coumaric acid
\end{tabular}


Phenolic acids identified in raw and cooked pearl millet. Phenolic acids identified in raw samples (powdered in the laboratory using electric grinder) were vanillic, syringic, salicylic, $\mathrm{p}$ $\mathrm{OH}$ benzoic acid, and melilotic acid, and in commercially milled flour sample were vanillic, syringic, p-OH benzoic acid, o-coumaric, and p-coumaric. Commercially milled pearl millet flour was identified as having a high quantity of phenolic acids when compared to raw samples. Phenolic acids identified in cooked recipes were vanillic, syringic, melilotic, Cis Ferulic, p-OH benzoic, and p-coumaric. Among all the cooked samples, the majority of phenolic acids were identified in ghes. Cis Ferulic was the unusual phenolic acid identified in rotla (Table 7, 8 and 9). There is no literature available regarding the phenolic acid in these cooked samples of pearl millet.

Table 8: Results of Phenolic Acids for Cooked Pearl Millet Based Recipes from Banaskantha

\begin{tabular}{cll}
\hline S. No. & \multicolumn{1}{c}{ Sample } & \multicolumn{1}{c}{ Phenolic Acid Present } \\
\hline 1. & $\begin{array}{l}\text { Rotla (milled and roasted } \\
\text { on dry heat) }\end{array}$ & Vanillic, syringic, melilotic, Cis ferulic acid \\
2. & $\begin{array}{l}\text { Sukhdi (milled and roasted } \\
\text { on dry heat) }\end{array}$ & Vanillic, syringic, p-OH benzoic acid \\
3. $\quad \begin{array}{l}\text { Khichdi (soaked and } \\
\text { cooked in open/closed pan) }\end{array}$ & $\begin{array}{l}\text { Vanillic, syringic, } \mathrm{p}-\mathrm{OH} \text { benzoic acid, melilotic } \\
\text { acid }\end{array}$ \\
& $\begin{array}{l}\text { Kooler (milled and mixed } \\
\text { raw with ghee and jaggery) }\end{array}$ & Vanillic, melilotic acid, p-coumaric acid \\
& $\begin{array}{l}\text { Ghes (hand pounded, } \\
\text { cooked with water and } \\
\text { buttermilk) }\end{array}$ & Vanillic, syringic, $\mathrm{p}-\mathrm{OH}$ benzoic acid, melilotic \\
&
\end{tabular}

The results of present study (phenolic acid: p-hydroxy benzoic acid, vanillic, syringic, ferulic, $\mathrm{p}$ coumaric) are similar to those brought back by Dyke and Rooney [51] in millets. The biosynthesis of phenolic compounds and organosulfur compounds is affected by different cultivation conditions, such as weather conditions, plant location, and harvest period [52].

Two classes of phenolic acids can be distinguished: derivatives of benzoic acid and derivatives of cinnamic acids. The hydroxyl benzoic acid content of edible plants is generally very low, with the exception of certain red fruits, black radishes, and onions. The hydroxyl cinnamic acids are more common than the hydroxyl benzoic acids and consist chiefly of pcoumaric, caffeic, ferulic acid, and sinapic acids. These acids are rarely found in the free form, except in processed food that has undergone freezing, sterilization, or fermentation. Phenolic compound ferulic acid has added health benefits as it battles cancer. Ferulic acid is the predominant bound phenolic form. The fact that ferulic acid could be identified in pearl millet emphasizes its potential role in the fight against cancer [53-58]. 
Table 9: The Color Reactions of Phenolic Acids

\begin{tabular}{|c|c|c|c|c|}
\hline $\begin{array}{l}\text { S. } \\
\text { No. }\end{array}$ & Phenolic Acid & $\overline{\mathbf{U V}}$ & $\begin{array}{l}\text { Diazotized } \\
\text { P-nitra Aline }\end{array}$ & $\begin{array}{l}\text { Diazotized } \\
\text { Sulphanic Acid }\end{array}$ \\
\hline 1. & P- hydroxy benzoic acid & - & Pink & Yellow \\
\hline 2. & Protocatechuic acid & - & Brownish- violet & Pink \\
\hline 3. & Vanillic acid & - & Purple & Orange \\
\hline 4. & Syringic acid & - & Blue & Red \\
\hline 5 a. & Cis-o-coumaric acid & Bluish yellow & Purple & Orange \\
\hline $5 b$. & Trans-o-coumaric & Bluish yellow & Purple & Orange \\
\hline 6. & Melilotic acid & - & Purple & Orange-yellow \\
\hline $7 a$. & Cis-p-coumaric acid & Blue & Blue & Pink \\
\hline $7 b$. & Trans-p-coumaric acid & Blue & Blue & Pink \\
\hline 8. & Caffeic acid & Blue & Brown & Pink \\
\hline 9a. & Cis-ferulic acid & Blue & Bluish-green & Purple \\
\hline $9 \mathrm{~b}$. & Trans-ferulic acid & Blue & Bluish-green & Purple \\
\hline 10a. & Cis-sinapic acid & Green & Blue green & Pink \\
\hline $10 \mathrm{~b}$. & Trans-sinapic acid & Green & Blue green & Pink \\
\hline 11. & Chlorogenic acid & Blue & Blue-purple & Orange-yellow \\
\hline
\end{tabular}

Rapid advances in science and technology, increasing health care costs, changes in food laws affecting label and product claims, an ageing population, and rising interest in attaining wellness through diet are the major factors that are fueling interest in such foods, and several clinical trials have been conducted to confirm the relationship between the components in the diet and risk of disease or health condition [59-62]. Further studies are therefore planned to assess the prevalence of these problems in the population of pearl millet belts. Studies are also suggested to quantify these polyphenols, assess their antioxidant activity levels, and also assess their health benefits by conducting clinical trials.

Authors' contribution: VN and EB designed the study, NS and MD contributed in the laboratory analysis and interpretation. All authors contributed to the final manuscript. None of the authors had a conflict of interest. None of the authors has conflicting interest in this program.

Acknowledgment: This research is funded by Harvest Plus, Washington DC, USA, Pearl millet project-Gujarat contract No. \#8220, IRB No, Fc Sc/FND/ME/48 dt 30/9/2010. Special thanks to Dr Sarma Mallubhotla and the entire pearl millet team-Rujuta Desai, Hetal Shah, Tosha Shahu, Himmat Makwana, Darshana Patel, Celin Masih, and my village subjects for their help in standardization and sample collection from Banaskantha, Gujarat, India. We extend our thanks to the staff and students of the phytochemistry laboratory, Department of Botany, MSU, and Dr JJ Dhaduk of SDAU, for their cooperation and support towards completion of this study.

\section{REFERENCES:}

1. Statistics Department (2010). Agriculture Department of Gandhinagar, Sector 10, Krishi Bhavan, Government of Gujarat, Gandhinagar 
2. Junagadh Agriculture University (2011) Research Recommendations 2010-11.

3. Nambiar VS (2011). Pearl millet project-Gujarat-Mid term result dissemination seminar. Palanpur. Banaskantha. 2011 18-19 April.

4. Gopalan C, Rama Sastri BV and Balasubramanian BC $\left(20^{06}\right)$. Nutritive value of Indian Foods, Eds. National Institute of Nutrition, Indian Council of Medical Research, Hyderabad, India.

5. Nambiar VS, Daniel M, Guin P. (2010) Characterization of polyphenols from coriander leaves (Coriandrum Sativum). Red Amaranthus (A. Paniculatus) and Green Amaranthus (A. Frumentaceus) using paper chromatography: and their health implications. J. Herbal Medicine and Toxicology. 4, 173-177.

6. Dicko MH, Hilhorst R, Gruppen H et al. (2002a) Comparison of content in phenolic compounds, polyphenol oxidases and peroxidases in grains of fifty sorghum varieties from Burkina Faso. J. Agric. Food Chem. 50, 3780-3788.

7. Romani A, Pinelli P, Galardi C et al. (2003) Flavonoids in leaves of black cabbage (Brassica oleracea var. acephala DC. subvar. viridis cv. serotina) grown on different soils and at different elevations. Italian. J. Food Science. 15, 197-205.

8. Stracke BA, Rufer CE, Weibel FP et al. (2009). Three-year comparison of the polyphenol contents and antioxidant capacities in organically and conventionally produced apples (Malus domestica Bork. cultivar 'Golden Delicious'). J. Agric. Food Chem. 57, 45984605.

9. Nambiar VS, Mehta R, Daniel M. (2005). Polyphenol Content of Three Indian Green Leafy Vegetables. J. Food Science and Technology. 42, 312-315.

10. Huang M T, Ferraro T. (1982) Phenolic compounds in food and their effects on health II. In Phenolics compounds in food and cancer prevention, Huang, M T., Ho, C. T., Lee, C. Y.; American Chemical Society, Washington D.C Hulse. Laing and Pearson. 1980: United States National Research Council/National Academy of Sciences. 1982. USDA/HNIS. 1984; 507, 8-34.

11. Asp NG. (1996) Dietary Carbohydrate Classification by Chemistry and Physiology. J. Food Chemistry. 7, 9-14.

12. Nambiar VS, Dhaduk JJ, Sareen N et al. (2011) A report on desk review of Pearl Millet (Pennisetum glaucum) with a focus on Banaskantha district of Gujarat, India. Report submitted to Harvest Plus/IFPRI/CIAT, Ottawa, Canada by The Department of Foods and Nutrition, Faculty of Family and Community Sciences, The Maharaja Sayajirao University of Baroda Vadodara - 390002, Gujarat, India. 1-90.

13. Mabry TJ, Markham KR, Thomas MB (1970). The systematic identification of flavonoids, Springer- Verlag, Berlin.

14. Harborne JB. (1951) Phytochemical Methods: A Guide to Modern Techniques of Plant Analysis, Chapman and Hall, London, UK.

15. Markham KR (1982) Techniques of Flavonoid Identification, New York, Academic Press.

16. Lowry OH, Rosenbrough NJ, Farr A et al. (1951). Protein measurement with the folin phenol reagent. J. Biol. Chem. 193, 265- 275. 
17. Singleton VL, Orthofer R, Lamuela RM. (1999). Analysis of total phenols and other oxidation substrates and antioxidants by means of Folin-Ciocalteu reagent. Methods Enzymology. 299, 152-158.

18. Prior RL, Wu X, Schaich K (2005) Standard methods for the determination of antioxidant capacity and phenolics in foods and dietary supplements. J. Agric. Food Chem. 53, 4290-4302.

19. Singh T, Brar JK, Bains K (2009). Nutritional evaluation of three cultivars of pearl millet [Pennisetum glaucum (L.) R.Br.]. J. Plant Science Research. 25, 79-82.

20. Nambiar, V.S, Dhaduk, J.J; Sareen, N; Shahu, T, Shah H and Desai R (2011). Potential Functional Implications of Pearl millet (Pennisetum glaucum) in Health and Disease. Journal of Applied Pharmaceutical Science. 01 (10);62-67.

21. Antinutritional factors content and Minerals availability of pearl millet (Pennisetum glaucum) as influenced by domestic processing method and cultivar. J. Food Tech. 2005, 3, 397-403.

22. Eltayeb M, Hassan AB, Sulieman MA et al (2007) Effect of processing followed by fermentation on antinutritional factors content of pearl millet (Pennisetum glaucum L.) cultivars. Pakistan. J. Nutr. 6, 463-467.

23. Elyas SHA, Tinay AH, Yosif NE et al (2002) Effect of fermentation on nutritive value and invitro protein digestibility of pearl millet. J. Food chem. 78, 75-79.

24. Borade VP, Kadam SS, Salunkhe DK. (1984) Changes in phytate phosphorous and minerals during germination and cooking of horse gram and moth bean (Qual Plant). J. plant Foods. Hum Nutr. 34, 151-157.

25. Kataria A, Chauhan BM, Punia D. (1989). Antinutrient and protein digestibility (in vitro) of mung bean as affected by domestic processing and cooking. J. Food chem. 32, 9-17.

26. Bravo L. (1998) Polyphenols Chemistry, dietary sources, metabolism and nutritional significance. Nutr. Rev. 56,317-333.

27. Chauhan BM, Sumeja N, Bhatc N. (1986) Nutritional value and fatty composition of some high yielding varieties of bajra. Bulletin of Grain Technology. 21, 41-42.

28. Mahajan S, Chaulian BM. (1987) Phytic acid and extractable phosphorus of pearl millet as affected by natural lactic acid fermentation. J. Sci. Food Agri. 41, 381-378.

29. Reddy NR, Sathe SK, Salumke DK. (1982) Phytates in legumes and cereals. Adv. Food Res. 28,1-9.

30. Harland BF, Oberleas D. (1987) Phytate in foods. World Nutr. Diet. 52, 235-259.

31. Pushpanjali S, Khokhar. (1996) In vitro availability of iron from some Indian vegetarian diets: correlations with dietary fiber and phytate. J. Food Chem. 56, 111- 114.

32. Duodu KG, Minnaar A, Taylor JRN. (1999) Effect of cooking and irradiation on the labile vitamins and anti-nutrient content of a traditional African sorghum porridge and spinach relish. J. Food Chem. 66, 21- 27.

33. Lonnerdal BO. (2000) Dietary factors influencing iron absorption. J. Nutr. 130, 1378513835. 
34. Sripriya U, Antony TS, Chandra. (1997) Changes in carbohydrate, free amino acids, organic acids, phytate and $\mathrm{HCl}$ extractability of minerals during germination and fermentation of finger millet (Eleusine coracana). J. Food Chem. 58, 345-350.

35. Carnovale E, Lugaro E, Lombardi-Boccia G. (1988) Phytic acid in faba bean and pea: effect on protein availability. J. Cereal Chem. 27, 1421-1423.

36. Yoon JH, Thompson LU, Jeukins DJA. (1983) Factors affecting starch digestibility and glycaemic response with reference to legumes. Am. J. Clin. Nutr. 38, 481- 493.

37. Knuckles BE, Kuzmicky DD, Betschart AH. (1985) Effect of phytate and partially hydrolyzed phytate on in vitro protein digestibility. J. Food Sci. 52, 1080- 1082.

38. Sharma CB, Goel M, Irshad M. (1978) Myo-inositol hexaphosphate as a potential inhibitor of amylase. J. Phytochemistry. 17, 201-204.

39. Elmaki HB, Bahiker EE, Tinay AH. (1999) Changes in chemical composition, grain malting, starch and tannin contents and protein digestibility during germination of sorghum cultivars. J. Food Chem. 64, 331- 336.

40. Elkalil EAI, Tinay AH, Mohamed BE et al. (2001).Effect of malt pretreatment on phytic acid and in-vitro protein digestibility of sorghum flours. J. Food Chem. 72, 29- 32.

41. Park SY, Chin K B. (2010) Evaluation of pre-heating and extraction solvents in antioxidant and antimicrobial activities of garlic, and their application in fresh pork patties. Int. J. Food Sci. Technol. 45, 365-373.

42. Strail P, Klejdus B, Kuban V. (2006) Determination of total content of phenolics compounds and their antioxidant activity in vegetables - Evaluation of spectrophotometric methods. J. Agric. Food Chem. 54, 607-616.

43. Robert. Seven potent natural cures in your kitchen. 2009.

44. Bichoff EM, Livingston AL, Booth AN. (1964) Tricin from alfalfa: Isolation and physiological activity. J. Pharm Sci. 53, 1411-1412.

45. Kuwabara H, Mouri K, Otsuka H et al. (2003) Tricin from a Malagasy connoraceous plant with potential antihistaminic activity. J. Nat Prod. 66, 1373-1375.

46. Hudson EA, Dinh PA, Kokubun $T$ et al (2000) Characterization of potentially chemopreventive phenols in extracts of brown rice that inhibit the growth of human breast and colon cancer cells. Cancer Epidemiology Biomarkers Prevention. 9, 11631170.

47. Cai H, Hudson EA, Mann P et al (2004) Growth-inhibitory and cell cycle-arresting properties of the rice bran constituent tricin in human-derived breast cancer cells in vitro and in nude mice in vivo. Br. J Cancer. 9, 1364-1371.

48. Verschoyle, RE, Greaves P, Cai H et al (2006) Preliminary safety evaluation of the putative cancer chemopreventive agent tricin, a naturally occurring flavone. Cancer Chem other Pharmacol.57, 1-6.

49. Duarte-Alameida JM, Negri G, Salatino A et al. (2007). Antiproliferative and antioxidant activities of an acylated tricin glycocide from sugarcane (Saccharum officinarum) juice. J. Phytochemistry. 68, 1165-1171. 
50. Middleton E Jr, Kandaswami C, Theoharides T (2000). The effects of plant flavonoids on mammalian cells:implications for inflammation, heart disease and cancer. Pharmacol. Rev.52, 673-751.

51. Saloum Sal. (1996) Antioxidant Flavonoids: structure, function and Clinical usage. Alternative Medicine Review. 1(2), 103-111.

52. Dykes L, Rooney LW. (2006) Review: sorghum and millet phenols and antioxidant. $J$ Food Science. 44, 236-251.

53. Xiaonan Lu, Carolyn F, Joseph R et al (2011) Determination of Total Phenolic Content and Antioxidant Activity of Garlic (Allium sativum) and Elephant Garlic (Allium ampeloprasum) by Attenuated Total Reflectance-Fourier Transformed Infrared Spectroscopy. J. Agric. Food Chemistry. 59, 5215-5221.

54. Hollman PC, Hertog MG, Katan M B. (1996) Role of dietary flavonoids in protection against cancer and coronary heart disease. Biochem. Soc. Trans. 24, 785- 9.

55. Kuhnau, J. (1996) The flavonoids. A class of semi essential food components: their role in human nutrition. World Rev. Nutr. Diet. 24, 117-91

56. Mehta AC, Sheshadri T R. (1959) The flavonoids as antioxidants. J. Sci. Ind. Res. 18B, 24-28.

57. Rice Evans CA, Miller N J, Paganga, C. (1996) Structure antioxidant activity relationship of flavonoids and phenolic acids. Free Radic. Biol. Med. 20, 933-56.

58. Verlangieri AJ, Kapeghian, J C, Eldean S et al (1985) Bush, M. Fruit and Vegetable consumption and cardiovascular mortality Med Hypothesis. 16, 7-15.

59. Vinson AJ, Hontz B. (1995) Phenol antioxidant index: comparative antioxidant effectiveness of red and white wine. J. Agric. Food Chem. 43, 401-3.

60. Nambiar VS, Chauhan S, Daniel M (2010) Polyphenols from Dark Chocolate and Their Effects on the Nutritional Status of the Middle Aged Gujarati Jains. International J. Pharmaceutical.Biological.Archive.1, 123-130.

61. Nambiar VS, Guin P, Parnami S et al. (2010) Impact of antioxidants from drumstick leaves on the lipid profile of hyperlipidemics. J. Herbal Medicine and toxicology. 2010, 4, 165-172.

62. Seshadri S, Nambiar VS. (2003) Kanjero (Digera arvensis) and Drumstick leaves (Moringa oleifera): Nutrient profile and potential for Human consumption. In: Plants in Human Health and Nutrition policy. World Review of Nutrition and Dietetics. Basel, Karger. 91. 41-56.

63. Nambiar VS. (2011) Age-defying foods. Ageing an interdisciplinary approach. ISBN No. 81-316-0389-X., Patel, S., Gandotra, V. Rawat Publications.:Jaipur. India. 223-230. 